IZA DP No. 9163

Remittances and Relative Concerns in Rural China

Alpaslan Akay

Olivier B. Bargain

Corrado Giulietti

Juan D. Robalino

Klaus F. Zimmermann

June 2015 


\title{
Remittances and Relative Concerns in Rural China
}

\author{
Alpaslan Akay \\ University of Gothenburg and IZA
}

\author{
Olivier B. Bargain
}

Aix-Marseille University and IZA

\author{
Juan D. Robalino \\ Cornell University
}

Klaus F. Zimmermann

IZA and Bonn University

\section{Corrado Giulietti}

IZA

\author{
Discussion Paper No. 9163 \\ June 2015
}

IZA
P.O. Box 7240
53072 Bonn
Germany

Phone: +49-228-3894-0

Fax: +49-228-3894-180

E-mail: iza@iza.org

\begin{abstract}
Any opinions expressed here are those of the author(s) and not those of IZA. Research published in this series may include views on policy, but the institute itself takes no institutional policy positions. The IZA research network is committed to the IZA Guiding Principles of Research Integrity.

The Institute for the Study of Labor (IZA) in Bonn is a local and virtual international research center and a place of communication between science, politics and business. IZA is an independent nonprofit organization supported by Deutsche Post Foundation. The center is associated with the University of Bonn and offers a stimulating research environment through its international network, workshops and conferences, data service, project support, research visits and doctoral program. IZA engages in (i) original and internationally competitive research in all fields of labor economics, (ii) development of policy concepts, and (iii) dissemination of research results and concepts to the interested public.
\end{abstract}

IZA Discussion Papers often represent preliminary work and are circulated to encourage discussion. Citation of such a paper should account for its provisional character. A revised version may be available directly from the author. 


\section{ABSTRACT \\ Remittances and Relative Concerns in Rural China ${ }^{*}$}

The paper investigates the impact of remittances on the relative concerns of households in rural China. Using the Rural to Urban Migration in China (RUMiC) dataset we estimate a series of well-being functions to simultaneously explore the relative concerns with respect to income and remittances. Our results show that although rural households experience substantial utility loss due to income comparisons, they gain utility by comparing their remittances with those received by their reference group. In other words, we find evidence of a "status-effect" with respect to income and of a "signal-effect" with respect to remittances. The magnitudes of these two opposite effects are very similar, implying that the utility reduction due to relative income is compensated by the utility gain due to relative remittances. This finding is robust to various specifications, controlling for the endogeneity of remittances and selective migration, as well as a measure of current migrants' net remittances calculated using counterfactual income and expenditures.

JEL Classification: C90, D63

Keywords: positional concerns, remittances, subjective well-being

Corresponding author:

Alpaslan Akay

University of Gothenburg and IZA

Schaumburg-Lippe-Str. 5-9

53113 Bonn

Germany

E-mail: alpaslan.akay@economics.gu.se

\footnotetext{
* The Longitudinal Survey on Rural Urban Migration in China (RUMiC) consists of three components: the Urban Household Survey, the Rural Household Survey and Migrant Household Survey. It was initiated by a group of researchers at the Australian National University, the University of Queensland and the Beijing Normal University. The survey has been supported by [the Chinese Foundation of Social Sciences and] the Institute for the Study of Labor (IZA), which also developed and provides the Scientific Use Files. We are grateful to participants at the session "Remittances, Job Search and Risk Attitudes in China" of the $10^{\text {th }}$ IZA/World Bank Conference on Employment and Development in Bonn for useful comments.
} 


\section{Introduction}

For the past three decades China has been experiencing an enormous movement of workers from rural towards urban areas. Recent estimates show that about 155 million people have left their rural residence to work in urban areas (Cai et al., 2011). Due to hukou restrictions, migrants' spouses and children are often left behind in villages, making remittances a crucial source of income to "compensate" for the migrant's absence. Estimates suggest that migrants sent about US \$30 billion to rural areas in 2005 (Gong et al., 2008). Such large cash flows have important and complex effects not only on the welfare of family members left behind, but also on the development, income distribution and welfare of rural villages (e.g., Acosta et al., 2008; Howell, 2014). This paper investigates how remittances affect the relative (or positional) concerns of rural households using subjective well-being (SWB hereafter) as a proxy for the experienced utility (Kahneman and Sugden, 2005).

An emerging strand of the literature has put forward the idea that individuals' welfare does not only depend on their income's absolute level but also on relative concerns, that is, on how individuals compare their income with that of other relevant people (Clark et al., 2008; Senik, 2008). The effect of relative concerns has been analyzed using SWB data from existing surveys (e.g., Ferrer-i-Carbonell, 2005; Clark et al., 2008) or by collecting survey experimental data (e.g., Solnick and Hemenway, 1998; Carlsson et al., 2007; Akay et al., 2012). ${ }^{1}$ Both approaches suggest that the relative income substantially affects individuals' utility. In the non-experimental approach, the role of relative concerns is captured by introducing the average income of other individuals (the reference group) as an additional control variable in SWB regressions conditional on individuals' absolute income and other characteristics. Evidence from developed countries suggests that the reference group's mean income negatively affects utility. Such a result is compatible with the presence of a status-effect reflecting feelings such as envy (Luttmer, 2005; Clark et al., 2008).

Yet, empirical studies from less developed or transition countries report small,

\footnotetext{
${ }^{1}$ The second approach to investigate the positional concerns is based on tailored survey experiments constructed to explicitly identify the relative concerns. This method allows for identifying positional concerns both for income and consumption of specific goods, such as cars and holidays (see, e.g., Alpizar et al., 2005; Carlsson et al., 2007; Solnick and Hemenway, 1998, 2005; Akay et al., 2011, 2013).
} 
sometimes positive impact from relative concerns (see for South Africa: Kingdon and Knight, 2007; Bookwalter and Dalenberg, 2009; Ethiopia: Akay and Martinsson, 2011; Akay et al., 2011; China: Appleton and Song, 2008; Knight et al., 2009; Knight and Gunatilaka, 2010; Akay et al., 2012; Poland: Senik 2004, 2005, 2008; Russia: Ravillion and Lokshin, 2000). ${ }^{2}$ One possible explanation of the positive effect is the presence of altruistic feelings towards other members with which the individual interacts in, e.g., the local community. Another explanation is that the income of other people acts like a signal-effect (or a "demonstration effect" or "tunnel effect" as coined by Hirschman and Rothschild, 1973) for the individual's own income potential and prospects, thus resulting in positive feelings (Senik, 2005).

By investigating the effect of the remittances received by the people in the reference group (relative remittances) on individuals' SWB, we build upon and bring together the literature strands on relative concerns and remittances. The remittances literature focuses mainly on the absolute effect of remittances on well-being, particularly in relation to income inequality and poverty (see e.g., Acosta et al., 2008; Akay et al., 2013). Remittances are expected to be positively associated with the well-being of individuals left behind since they represent an additional (or substitutive) income source. In addition, however, remittances may change the income distribution and the relative income position of households within the sending village. That is, remittances might change the reference group’s income position, thereby triggering a "status" or a "signal" effect to the extent that individuals might also be concerned with the remittances that other households receive.

Our analysis, based on the Rural to Urban Migration in China (RUMiC) dataset, provides novel and striking results on rural households' relative concerns with respect to both rural income and remittances. The first result is that the definition of income matters when identifying relative concerns in a regression framework. A measure of the overall household income alone might not be able to identify the true effect. Second, we show that while a status-effect among rural households exists, the magnitude and significance of such an effect depends on the model specification. Third, by decomposing the overall household income into the part pertaining to remittances and the part pertaining to activities carried out in the village (henceforth:

\footnotetext{
${ }^{2}$ See also the comprehensive survey by Clark and Senik (2010).
} 
rural income), we find that rural households experience both status and signal effects at the same time. In particular, households exhibit a strong status-effect with respect to rural income and an equally strong signal-effect with respect to remittances. This result suggests that these two effects may be neglected when analyzing relative concerns using aggregate income measures. Fourth, results are very stable across heterogeneous groups and overall insensitive to the definition of the reference group. Last but not least, we take into account the role of selectivity into migration by both estimating Heckman-type regression equations and calculating the counterfactual income and expenditures distributions pertaining to migrants.

The paper is organized as follows: Section 2 provides information about the data and descriptive statistics. Section 3 outlines the econometric approach. Section 4 and 5 report the results from our baseline and additional models, respectively. Finally, Section 6 concludes.

\section{Data}

\subsection{The RUMiC Dataset}

We employ data from the Longitudinal Survey on Rural to Urban Migration in China (RUMiC), which consists of three distinct surveys: the Urban Household Survey (UHS), the Rural Household Survey (RHS), and the Migrant Household Survey (MHS). ${ }^{3}$ Our paper is based on the first wave of the RHS. Data were collected at the beginning of 2008, with most information (e.g. migration, income) referring to $2007 .{ }^{4}$ The RHS covers the nine largest migrant sending provinces of China. ${ }^{5}$ The survey was conducted using random samples from the household income and expenditure surveys carried out in rural villages by the China National Bureau of Statistics, thus constituting a representative sample for these provinces.

The dataset has rich information about demographic and socio-economic characteristics of household members, including questions on physical and mental

\footnotetext{
${ }^{3}$ For an extensive description of RUMiC, see Akgüc et al. (2014).

${ }^{4}$ The global economic crisis has affected both migration and return decisions. At the end of 2008, around 23 million migrants returned to their rural villages (National Bureau of Statistics of China 2010). Hence, the data used in our paper refer to a time period before the crisis. However, we have also checked the robustness of our results by using the waves collected in 2009 and 2010 (estimates available upon request.

${ }^{5}$ These are: Anhui, Chongqing, Guangdong, Hebei, Henan, Hubei, Jiangsu, Sichuan and Zhejiang.
} 
health, life events, and social networks. We supplement the main dataset with two ancillary modules collected parallel to RUMiC: the income-expenditure household module, which contains information on consumption, assets, and expenditure at the household level, and the rural community survey, which includes village-level information such as economic conditions, migration in and out of the village, and public expenditure. A village cadre is usually interviewed about these. Below we describe in detail the key variables used in the analysis. Appendix A reports summary statistics of all selected variables.

\subsection{Measures of Well-being}

The literature has identified several measures to proxy SWB (Frey and Stutzer, 2002; Dolan et al., 2008). These are generally based on survey questions about "happiness,” "life-satisfaction," or "mental health.” In order to measure SWB, we constructed an index based on the 12 mental health questions contained in the RUMiC's General Health Questionnaire (GHQ-12). ${ }^{6}$ The literature has widely employed the GHQ-12 index (see e.g., Clark and Oswald, 1994, 2002; Akay et al., 2012, 2013). Each question allows responses with scores between 0 (high levels) and 3 (low levels). To obtain the GHQ-12 index, we sum the scores of the 12 questions, obtaining an index ranging from 0 to 36 and then we reverse the scale so that low levels indicate low SWB and high levels correspond to high SWB. We also constructed a "happiness" index by using the question "How happy are you when you consider each aspect of your life?” contained in the GHQ-12 questionnaire. We use this index to test the robustness of the results.

The distribution of our index resembles that of other SWB studies (see, e.g., Winkelmann and Winkelmann, 1998). The distribution of the index is left-skewed, with few people reporting very low levels of SWB. In Figure 1, we split the distribution into households who receive remittances and those who do not. The figure suggests no systematic difference in terms of SWB between the two groups.

\footnotetext{
${ }^{6}$ Our well-being index is based on summing each question in the General Health Questionnaire (GHQ12). See Appendix B for the details of GHQ-12 questionnaire and Goldberg (1978) for an introduction to the questions and use of the GHQ. However, as discussed in Hankins (2008), this approach might be problematic if the variances of the individual responses are different, in particular between positively and negatively phrased questions. Fortunately, we do not find significant differences in our sample.
} 
Figure $1(\mathrm{a}$ and $\mathrm{b})$ about here

\subsection{Sample and Descriptive Statistics}

The sample consists of individuals aged between 16 and 70 who report SWB information. We cover a total of 11,624 individuals across 6,063 households.

Migrants. One of the key variables is individuals' migration status. This is constructed using the question, "How many months did you live away from the local township in 2007?” combined with an ancillary question on where the person lived during his or her absence ("If you lived outside the local township for more than three months in 2007, where did you live mainly?”). A migrant is defined as someone who lived in urban areas for at least six months during 2007. A household might have more than one migrant and the migrant can be the head, spouse, or another household member. Given this definition, our data show that 39\% of households have at least one migrant. Note that although the SWB information is missing for individuals who currently live in the city, the survey respondent reports all socio-demographic and economic information for absent household members. We also construct an indicator for whether individuals have migrated in the past (i.e., before 2007).

Rural Income and Remittances. The other two key variables for this study are the components of the overall income of households: rural income and the remittances sent by migrants who live in the city. The rural income pertains to a mix of different activities carried out in the village including wage employment, self-employment, and farming. We have detailed information about the various sources of income, which we use in the analysis. Remittances are proxied by a variable capturing the income from working in activities conducted outside the village. Income and remittances are measured at the household level in thousands of Chinese Yuan (CNY). While we explore different definitions, our preferred measures for income and remittances are expressed in logarithm and are calculated in per capita terms using the modified equivalence scale suggested by the OECD. ${ }^{7}$

\footnotetext{
${ }^{7}$ To calculate the per capita income and remittances, we divide the levels by the weighted number of family members left behind, i.e. excluding migrants. The weights used to calculate equivalent income is 1 for the household head, 0.5 for each adult, 0.3 for children.
} 
Key statistics. In Table 1 we report descriptive statistics of SWB, along with various definitions of income and remittances (see Appendix A for the statistics of additional variables). In addition to showing the statistics for the whole sample, we also split the list into households who receive and do not receive remittances. The average SWB level is 28.08. The difference between remittance receivers and non-receivers is very small, albeit statistically significant (28.27 versus 27.86 , p-value $=0.000)$. The mean level of remittances among receivers is 8,471 CNY. For these households, remittances constitute more than one third of the household income. Households with remittances report an overall income of 24,990 CYN (found by summing rural income and remittances), which is lower than that of households without remittances $(26,784$ CYN). However, the income difference between these two groups is not comparable since the household (and the labor force) sizes differ systematically due to absent members who migrated. If we compare per capita figures, which account for current household size, we note that the total incomes of these two groups are rather similar: 18,049 CYN for households without remittances versus 18,244 CYN (6,264 + 11,980) for households with remittances.

Table 1 about here

\section{Econometric Approach}

\subsection{Model Specification}

We estimate a series of alternative SWB regressions. In addition to income level and other characteristics, the standard approach in the literature identifies relative concerns through using the average income of individuals in the reference group as a control variable (e.g., Ferrer-i-Carbonell, 2005; Akay et al., 2012, 2013). Similarly, our regressions include the reference group's average income, but we decompose it into average rural income and average remittances. Hence, our specification includes measures for absolute $\left(Y_{i}\right)$ and relative income $\left(Y_{i}^{r}\right)$ and absolute $\left(R_{i}\right)$ and relative remittances $\left(R_{i}^{r}\right)$, where $r$ is the reference group. Accordingly, the baseline model reads as follows: 


$$
S W B_{i}^{*}=\alpha_{1} \log \left(Y_{i}\right)+\rho_{1} \log \left(Y_{i}^{r}\right)+\alpha_{2} \log \left(R_{i}\right)+\rho_{2} \log \left(R_{i}^{r}\right)+x^{\prime} \beta+\eta_{k}+\varepsilon_{i}
$$

In equation (1) the dependent variable SWB is considered to be latent for each individual $i$, suggesting that an appropriate model would be an ordered probit. However, previous studies show no appreciable difference between estimating SWB models with linear or latent dependent variable specification (Ferrer-i-Carbonell and Frijters, 2004). Hence, in line with the bulk of the SWB literature, we estimate our models using OLS and only check the sensitivity of the results using ordered probit at the end. The estimates of parameters $\alpha_{1}$ and $\alpha_{2}$ are expected to be non-negative since higher levels of income and remittances imply more consumption possibilities and possibly higher SWB. However, the "marginal utility” of income and remittances might differ. We carry out extensive sensitivity checks surrounding the estimation of $\alpha_{1}$ and $\alpha_{2}$.

The key parameters to our analysis are $\rho_{1}$ and $\rho_{2}$, which capture the relative income and relative remittance effects, respectively. The corresponding variables are defined as follows:

$$
\begin{aligned}
& Y_{j}^{r}=\frac{1}{N_{j}} \sum_{1}^{N_{j}} Y_{S} \\
& R_{j}^{r}=\frac{1}{N_{j}} \sum_{1}^{N_{j}} R_{S}
\end{aligned}
$$

where $N_{j}$ is the number of individuals within the reference group $j$ (e.g. a county). The signs of $\rho_{1}$ and $\rho_{2}$ are not obvious a priori. Finding that both income and remittances of the reference group are negatively correlated with SWB could reflect the presence of envy or jealousy. As described in the introduction, we refer to this situation as the status-effect with respect to both income and remittances. On the contrary, both estimates could be positive, in which case we find a signal-effect with respect to both income and remittances reflecting individual's own income potential and prospects. Indeed, the relative income and remittances could have different signs, implying a status-effect for one variable and a signal-effect for the other. Equation (1) also includes controls for socio-demographic characteristics $(x)$ such as age, sex, and marital and health status; the term $\eta$ refers to indicators for provinces. The standard errors are clustered at the household level, though the analysis explores other clustering criteria as well. 


\subsection{Measuring Reference Groups}

One of the crucial issues is how to define the reference group. While reference groups are usually unknown, the literature suggests two distinct approaches to identify groups to which individuals compare their income. The first method is to use ad-hoc criteria to define the groups based on socio-demographic similarities (e.g., Clark and Oswald, 1996; McBride, 2001, Ferrer-i-Carbonell, 2005; Luttmer, 2005). The second method directly asks people to whom they compare their income. The difference between these two approaches has been found to be minimal (Clark and Senik, 2010).

In a survey among rural households in China, Knight et al. (2009) explicitly ask rural households about their reference groups. About $70 \%$ of the respondents report that they compare their income with that of village members. Our dataset includes an identifier for the village where the household is located. Thus it would be optimal to use village residents as the reference group. However, the sample size is not large enough to construct an income variable that is precise enough. ${ }^{8}$ Instead, we refer to a slightly larger orbit of comparison and use Chinese "counties." Counties are the administrative level above villages and below provinces. In our data, there are a total of 82 counties (see Figure 2).

While the county identifies the baseline reference group, we also define narrower reference groups by combining additional dimensions of comparison, such as similarity in household migration characteristics (i.e., the reference group is households within the same county that have migrants) or similarity in employment status (i.e., the reference group is wage workers within the same county). In our analysis we show how the results are sensitive to the definition of the reference group.

\section{Results}

We present our results as follows. As a preliminary step, we show SWB determinants in rural China. Second, we outline results for relative concerns with respect to overall household income. Third, we disentangle the components of overall income in order to study the role of relative remittances. Fourth, we investigate the role of income inequality and observed heterogeneity, and check the sensitivity of results to

\footnotetext{
${ }^{8}$ On average, 10 households are sampled in each village.
} 
alternative reference groups. We reserve the next section of the analysis for migration selectivity and additional robustness checks.

\subsection{Determinants of Subjective Well-Being in Rural China}

In Table 2 we present the results of a standard OLS regression of SWB, where we include individual socio-demographic and economic controls as well as variables related to the household, including household members' migration status. The scope of this regression is to show how our results compare with those of existing SWB studies. We present results for the whole sample as well as separately for households receiving and not receiving remittances. The signs, magnitudes, and statistical significance of the estimates pertaining to socio-economic and demographic characteristics align with other studies (e.g., Dolan et al., 2008; Knight et al., 2009; Akay et al., 2012). The pattern of results is also similar across households who receive remittances and those who do not, albeit there are differences in the magnitude and sometimes the sign of some estimated parameters. Below, we briefly discuss and interpret the benchmark results.

Rural Income and Remittances. In the first panel of Table 2, we include the two components of household income (rural income and remittances), indicators for economic activity, and other wealth measures. As one would expect, rural income is positively correlated with SWB. The magnitude of this correlation is similar across specifications and is usually statistically significant, with the exception of the specification related to household members in the remittance-receiving group. Such positive correlation is consistent with the results for developed countries (e.g., Dolan et al., 2008) and also with previous evidence from China (Knight et al., 2009; Knight and Gunatilaka, 2010; Akay et al., 2012).

While we investigate the role of remittances thoroughly later on, at this point we note that remittances positively correlate with SWB, with estimates that are statistically significant in all specifications. Furthermore, the magnitude of the "marginal utility of remittances" is close to the "marginal utility of rural income". In fact, the difference between the two estimates is not statistically significant $(0.210$ versus 0.175 , pvalue $=0.7$ for the whole sample). 
Our regressions include additional economic and wealth-related variables. For example, being a salaried worker, a farmer, or self-employed is associated with higher well-being than the reference category (which is the group formed by the inactive population and those who do household work). However, such an effect is economically and statistically larger only for households not receiving remittances. Furthermore, working more hours leads to lower utility, particularly for households without remittances (see Pouwels et al., 2008). Conditional on other wealth and income measures, land size is negatively correlated with SWB, with a larger effect found among remittance-receiving households. One possible interpretation is that individuals in this group need additional labor in order to maintain the land and carry out agricultural activities after the migrant has left. Finally, and perhaps as expected, both house size and house value are positively correlated with SWB, with a stronger effect for house size.

Socio-demographic Characteristics. The estimates for age and age-squared suggest the existence of a U-shaped relationship, which very much aligns with international evidence (see Blanchflower and Oswald, 2008). Since the sample of left-behind individuals is relatively "old" (the average age is 48), the minimum point of the age effect is located between 55 and 60. Males report higher SWB compared to females, although it is important to point out that the group of left-behind males is highly selfselected. In line with other studies, we observe a SWB “premium” for marriage (e.g., Helliwell, 2003). Health is a strong predictor of SWB. Individuals experience lower SWB as their health worsens (the omitted category is "very good health"). We control for two additional health-related determinants: height and weight. Weight appears to be positively correlated with SWB, while height seems to be unrelated to it. Education is another strong predictor of SWB, once again aligned with other studies (e.g., Helliwell, 2003). The few households holding urban hukou (6.23\% of the total) experience higher SWB, though the effect is found only among those who receive remittances. While household size is strongly associated with SWB, we found only a weak relationship with the number of children, in line with the reported findings in Dolan et al. (2008).

Migration Characteristics. We control for a rich set of variables capturing the households' migration characteristics. First, we include dummy variables to capture 
the number of migrants in the households (the base category is "no migrants"). In general, having one or more migrants in the household is negatively associated with SWB. The negative sign is compatible with a migrant's absence having larger costs than benefits in terms of well-being. Recent literature has shown that the absence of household members due to migration can have both positive and negative effects on well-being determinants, such as education and self-employment. For example, Biavaschi et al. (2015) found that being left-behind triggers a stronger influence of older siblings on the schooling performance of the youngest. On the other hand, Giulietti et al. (2013) found that left-behind individuals are less likely to be selfemployed when compared to return migrants and individuals who live in non-migrant households. Since these factors are already controlled for in the regression, we interpret the negative estimate as the psychological cost associated with the migrant's absence (albeit often temporary). Since there are no appreciable differences between whether the migrant is the household head or the spouse, the migration effect's size and magnitude does not seem to depend on which family member has migrated.

Table 2 about here

\subsection{Relative Concerns in Rural China}

To go one step further, we investigate relative concerns with respect to total household income and report the results in Table 3. For conciseness, we report only the absolute and relative income estimates. Bear in mind that the specifications include the same explanatory variables as in Table 2, except for the addition of the reference group's average income. In the first three columns we check the role of relative concerns by holding the reference group (the local county) constant and check the effect of functional form and measure of income used.

When we use a definition of income in level (first column) or in per capita terms (second column), the relative concerns parameter estimate is economically and statistically insignificant. In contrast, when we use our preferred definition (log per capita income) the estimate for relative income is large, negative, and statistically significant. While we are confident about the choice of our definition, as many SWB studies have adopted it before (see e.g. the comprehensive review by Dolan et al., 2008), we note that such a result is rather puzzling. 
Table 3 about here

Reference Groups. In the remaining columns in Table 3, we explore different reference groups that are alternative to the one "all other people in the same county." In this exercise, we hold the definition of income (log per capita) constant. We first narrow down the reference group to "all other people in the same village." In this case, it should be noted that a smaller number of individuals is used to calculate the average per capita income (there are on average 10 households per village, resulting in just about 30 non-migrant individuals per village: a minimum of 13 and a maximum of 61). Despite this, results are similar to the baseline, in which we used a larger number of individuals (on average 97 households and 315 individuals) to calculate the reference group's income. $^{9}$

When we refine the reference group to all other people in the same county with and without wage employment separately, we once again find estimates that are comparable to the baseline reference group. Finally, we obtain very similar results when we look separately at all other people in the same county who are below and above 40 years old. These results suggest that the relative income effect is not particularly sensitive to more precise definitions of the reference group.

\subsection{Remittances and Relative Concerns}

Baseline Results. We now decompose the overall household income into income generated by the activities of people left behind (rural income) and the remittances sent by migrants. Using these two components, we estimate the full model specification presented in equation (1). We are mainly interested in absolute and relative income ( $\alpha_{1}$ and $\rho_{1}$ ) and absolute and relative remittances ( $\alpha_{2}$ and $\rho_{2}$ ). Table 4 presents the results.

Similarly to the results in Table 3, household (rural) income is positive and significant across all model specifications. Likewise, the relative (rural) income is statistically significant, with a large negative magnitude $(-0.852) .{ }^{10}$ Both absolute and relative

\footnotetext{
${ }^{9}$ Note that income and remittance variation is at the household level. This is why 10 households per village do not provide enough variation.

${ }^{10}$ One important remark is that when we include remittances in the regression, relative concerns are not sensitive to the definition of income. We have estimated alternative models using per capita income
} 
remittances are positive, but only the latter is statistically significant, with a large estimate (0.865). Our baseline results imply that rural individuals experience a substantial status-effect with respect to income and an equally large signal-effect with respect to remittances. The result is very similar when we narrow the sample to include only household heads.

Who is affected? Relative concerns with respect to remittances might be different among households who receive the remittances (around $48 \%$ of the sample) and those who do not. In the third and fourth column of Table 4, we analyze the results separately for the two groups. The household income is positive for both groups, albeit stronger for households without remittances. Interestingly, the relative concerns with respect to income are present only among households not receiving remittances. These results are consistent with the fact that the main source of income for households without remittances is rural income, while the other group also relies on money sent by migrants. Remittances are found to be positively related to SWB among remittance-receiving households, yet the effect is not precisely estimated. On the contrary, relative remittances positively influence both households' SWB, although the effect is almost twice as large for households receiving remittances.

Reference Groups. We explore the sensitivity of relative remittances to the definition of the reference group. To do so, we keep the county as the regional orbit and add some additional criteria. The first two alternative reference groups involve similarity in age and wage employment status. We find very similar results to those in the first column. In the last column, we recognize that not all households with migrants receive remittances. We explore what happens if we calculate relative income and remittances among households with and without migrants. The results are slightly different than those in the first column, yet the pattern is the same. In particular, the signal-effect of relative remittances is stronger while the status-effect of relative income is weaker.

Does income inequality explain the results? Due to their substantial size, remittances are expected to affect the income distribution within the receiving regions. The empirical evidence, mostly based on international migration, suggests that remittances

without log transformation, finding results remarkably similar to those obtained with using our preferred definition of income. 
either increase or decrease income inequality (Acosta et al., 2008). Moreover, income inequality might have a distinct effect on SWB, but this could be "confounded" by the relative income effect (see on this point, e.g., Senik, 2008). In order to further control for the additional effect of income inequality on SWB, we control for the GINI index calculated within the reference group. In particular, we calculate income inequality in the county using both the pre- and post-remittances per capita household income. This allows us to assess the remittances' contribution to income inequality in the region. Interestingly, we find that remittances are associated with lower or higher income inequality depending on the county. Around $46 \%$ of the counties exhibit higher income inequality after receiving remittances.

Results in the last column in Table 4 show that accounting for differential income inequality before and after remittances does not affect our baseline results. The sign of the correlation is negative-implying that increases in inequality due to remittances reduce SWB-but is statistically insignificant. ${ }^{11}$ As expected, the strength of the signal from the remittances in the reference group is slightly reduced; yet compared to the baseline, the reduction is not statistically significant.

Table 4 about here

\subsection{Heterogeneity}

Our sample comprises heterogeneous groups with respect to economic activity, migration status, and other characteristics. We therefore investigate how our main results differ across various groups through a simple modification of the baseline econometric model. We first define a dummy variable indicating a specific individual characteristic, $D$, and then we interact $D$ and $(1-D)$ with the absolute and relative income and remittance variables. We outline the modified econometric specification below. In Table 5 we only present the estimates of $\alpha_{21}, \alpha_{20}, \rho_{21}$ and $\rho_{20}$.

\footnotetext{
${ }^{11}$ While here we focus on the "change" of income inequality to identify which part is due to remittances, an important issue is the effect of the inequality "level" on SWB. In unreported results, we estimate two SWB regressions that include the inequality "before" and "after" remittances. Similarly to other studies, we find that income inequality is positively correlated with SWB (Senik, 2008; Kingdon and Knight 2007; Knight et al, 2009). While one might expect income inequality to affect utility negatively, inequality could also capture rural households' income possibilities, therefore positively correlating with SWB.
} 


$$
\begin{array}{r}
S W B_{i}^{*}=\alpha_{1} \log \left(Y_{i}\right)+\rho_{1} \log \left(Y_{i}^{r}\right)+\alpha_{21} \log \left(R_{i}\right) * D_{i}+\alpha_{20} \log \left(R_{i}\right) *\left(1-D_{i}\right) \\
+\rho_{21} \log \left(R_{i}^{r}\right) * D_{i}+\rho_{20} \log \left(R_{i}^{r}\right) *\left(1-D_{i}\right)+x^{\prime} \beta+\gamma \theta_{2} * D_{i}+\eta_{k}+\varepsilon_{i}
\end{array}
$$

Economic Characteristics and Income Distribution. A large part of households have members who are in wage employment. Wage employment could influence both the role of absolute and relative remittances. We investigate this aspect in the first two columns in Table 5. The first remarkable aspect is that wage earners exhibit a negative correlation with remittances sent by other household members. This suggests a sort of dissatisfaction or envy effect, although the effect is small (-0.099) and statistically insignificant. The opposite effect—slightly larger (0.124) but statistically significant-is found among individuals who are not wage earners. One possible explanation is that since wage earners are individuals who are likely to migrate in the near future, they tend to compare their income with that of migrants in the local region (using remittances as a proxy for the urban wage) and this generates a statuseffect. Furthermore, we find that the remittance signal-effect is smaller for wage workers than for other individuals (0.647 vs. 0.901).

Next, we compare farmers with other individuals in the third and fourth columns. Interestingly, the income status-effect and the remittance signal-effect are larger in terms of absolute magnitude for this group. In the fifth and sixth columns we compare individuals living in counties where the share of wage workers is above the median of all counties versus those living in the remaining counties. In areas where wage workers are overrepresented, the income status-effect is relatively stronger and the remittance signal-effect is relatively weaker, aligning with the results in the first two columns.

The second set of results focuses on the reference groups' income distribution and results can be found in columns five and six. We hypothesize that relative concerns with respect to income and/or remittances might be different depending on the regional income level. We hence generate an indicator for counties with income above the median of all counties. Interestingly we find that the relative income statuseffect is much stronger for relatively richer counties, and in fact, it is close to zero for relatively poorer counties. It seems that a higher economic level in the region relates to a higher relative concerns (Clark et al., 2008). On the contrary, the signal-effect 
from remittances is weaker in relatively richer counties.

We then investigate in columns seven and eight the role of income inequality by interacting our key variables with an indicator for counties where remittance flows reduced the inequality from rural incomes. We find a lower status-effect with respect to income in regions where income inequality is decreased. The signs and magnitudes of other estimates are very similar to the baseline model, implying once more that income inequality does not play a major role in explaining our results.

Migration Experience and Intensity. Individuals' migration status might also affect both the status- and the signal-effect. We investigate how our results differ depending on an individual's migration experience as well as on the migration "intensity" within the reference group. We report the results in the lower panel of Table 5. The results are striking: in column one we find that only individuals in households without migrants experience the status-effect with respect to income while the signal-effect is very strong and statistically significant for individuals from households with at least one migrant.

We further create an indicator for counties with a number of migrants above the median. We consistently find that the relative income effect is only significant in counties where households have fewer migrants, and they hence rely more on the income earned with activities in rural areas. On the contrary, the relative remittance effect is much stronger in counties with relatively more migrants (the third and fourth columns). In the fifth and sixth columns we explore the results depending on whether the individual migrated in the past or not. The results between the two groups resemble each other, indicating that previous migration experience does not bear consequences on the current status- or signal-effect.

\section{Table 5 about here}

Individual Heterogeneity. In the last columns we explore the heterogeneity of the results through select socio-demographic characteristics. In the seventh and eighth columns in the lower panel of Table 5 we distinguish between individuals who are above and below 40 years old. We find a much stronger status-effect from relative income among the young and a much stronger signal-effect from relative remittances 
among the older. This suggests stronger "income competition" among the young. Furthermore, it is important to remind the reader that in the context of rural China, remittances are often sent to support elderly parents; this could explain the discrepancies in the signal-effect from remittances. On the contrary, education does not seem to play a strong role when we distinguish between individuals who have education above or below the median (the threshold is eight years of education).

\section{Robustness and Self-Selection}

In this section we first investigate the robustness of our results with some additional tests. We then explore the potential confounding role of selectivity into migration. Finally, we present a counterfactual analysis accounting for the absent migrant's income and expenditures.

\subsection{Further Robustness Checks}

Additional Controls and Clustering. We investigate the sensitivity of the results with respect to alternative specifications and measures. In unreported results, we first look at the role of control variables. We compare specifications where we progressively add control variables into equation (1). Results are remarkably robust with respect to specifications with few or more control variables. We note the important role of geographic indicators in the regressions to capture regional differences such as prices. In our baseline, we use province fixed-effects. In the models in which we define the reference group with criteria narrower than the county, we also introduce county fixed-effects and find essentially similar results. Additionally, we experiment what happens when we cluster standard errors at the county level instead of the household level. As one would expect, the standard errors become somewhat larger but the statistical significance of our key results is only partially affected. ${ }^{12}$

Estimators and Reference Income. Throughout the paper we use a linear model as our preferred specification, also due to the fact that ordered probit models do not allow for easy ceteris paribus interpretation of the parameter estimates. For robustness, we reestimate the baseline using ordered probit. The first column in Table 6 presents the results. The key parameters' signs and significance are very much in line with our

\footnotetext{
${ }^{12}$ Results are available upon request.
} 
baseline OLS. In the second column, we use median instead of average income and remittances, as the median is more robust to extreme values within reference groups. However, this particular measurement does not seem to affect our results.

Unobserved Heterogeneity. Our approach and data do not allow us to control for the time-invariant unobserved individual effects (e.g., genetic predisposition, personality characteristics). These characteristics are found to be very important in explaining individuals' SWB (Boyce and Wood, 2011). In this robustness check, we follow the strategy developed in Akay et al. (2012) to partially control for these latent characteristics. The authors suggest using GHQ-11 instead of GHQ-12 as a response variable and to use the twelfth question ("How happy are you when you consider each aspect of your life?”) as a control variable to proxy for time-invariant individual characteristics. The results in the third column in Table 6 suggest only minor changes with respect to our baseline.

\subsection{Selective Migration}

There are different potential sources of self-selection that might affect our result. One of the most important relates to whether people's intrinsic preferences towards status generate a strong incentive to migrate. Stark and Yitzhaki (1988) and Stark (2006) discuss the fact that the desire for income status may be one of the reasons individuals decide to migrate. Using a household panel survey from two provinces in rural China, Wu (2008) finds evidence supporting this argument. The paper reports that lower income positions increase the chance that some household member migrates. We tackle this question by using a Heckman-type selection specification to model the migration decision.

One of the features of our sample is that we have socio-demographic characteristics (except the SWB information) for individuals who are currently migrants in the urban areas. This allows us to specify a selection model as follows. The individual decides to stay or migrate as a function of absolute and relative income and remittances, plus a set of other determinants included in $z_{i}$ :

$s_{i}=1\left(\alpha_{1}^{S} \log \left(Y_{i}\right)+\rho_{1}^{S} \log \left(Y_{i}^{r}\right)+\alpha_{2}^{S} \log \left(R_{i}\right)+\rho_{2}^{S} \log \left(R_{i}^{r}\right)+z^{\prime} \gamma+w_{i}>0\right)$,

where $\boldsymbol{s}_{\boldsymbol{i}}$ is an indicator taking the value 1 if the individual is a migrant (which in our 
data corresponds to whether the SWB of individual $i$ is observed). $\alpha_{1}^{S}, \rho_{1}^{S}, \alpha_{2}^{S}, \rho_{2}^{S}$ and $\gamma$ are the first-stage parameters to be estimated. $w_{i}$ is the error term of the sample selection equation assumed to be normally distributed with a zero mean and unit variance. In the second stage we estimate the SWB equation conditional on selection. The selection corrected SWB equations are defined as follows:

$S W B_{i}^{*}=1\left(\alpha_{1}^{t} \log \left(Y_{i}\right)+\rho_{1}^{t} \log \left(Y_{i}^{r}\right)+\alpha_{2}^{t} \log \left(R_{i}\right)+\rho_{2}^{t} \log \left(R_{i}^{r}\right)+x^{\prime} \lambda+u_{i}>0\right.$,

$S W B_{i}=S W B_{i}^{*} \times s_{i}$

Equation (5) is the target SWB equation and our aim is to estimate the selection corrected absolute and relative income and remittances, given with parameters $\alpha_{1}^{t}, \rho_{1}^{t}, \alpha_{2}^{t}$, and $\rho_{2}^{t}$. We estimate the equation (4) and (5-6) simultaneously. In this model, the error terms are specified as $u_{i} \sim N\left(0, \sigma_{u}^{2}\right), w_{i} \sim N(0,1)$, and the correlation between equations is $\rho_{u w}=\operatorname{Corr}\left(u_{i}, w_{i}\right)$.

Identification requires at least one exclusion restriction, which will be used in the selection equation and excluded from the main equation. This implies that we need to seek a variable that affects SWB only through migration, but not directly. We have various instrumental variables that we can exploit. Our favorite instrument is based on the distance of the village from: (i) the nearest government building, and (ii) the nearest port or station. Distance is categorized in a variable with five values, ranging from the shortest to longest. By combining the two distance variables, we can introduce 10 dummy variables in the selection equation. The other instrument is the birth order of the individual. Villages close to government buildings or stations are those where individuals are more likely to migrate out. Similarly, first-born are less likely to migrate-since they often are responsible for taking care of the family. Hence both instruments are thought to influence migration without having a direct effect on SWB.

One important remark is that results from the selection equation suggest that relative income and remittances are positively correlated with the migration decision, supporting the findings of Stark (2006) and Wu (2008). ${ }^{13}$ The correlation between

\footnotetext{
${ }^{13}$ Although we do not report first stage regression results here, the results align with the literature and can be provided upon request.
} 
equations is significant (between -0.10 and -0.15 , depending on the instruments used). Our main interest is on the corrected estimates of absolute and relative income and remittances ( $\alpha_{1}^{t}, \rho_{1}^{t}, \alpha_{2}^{t}$, and $\rho_{2}^{t}$ ). The estimates presented in the fourth and fifth columns in Table 6 are very similar to those in Table 4, suggesting that our main results are robust to self-selection into migration. ${ }^{14}$

\subsection{Counterfactual Income and Net Remittances}

The income level of households with migrants is expected to be comparatively lower than that of households without migrants, since the former does not account for the absent migrants' income. The migrants' only contribution to the household income is remittances. Failure to account for the potential income contribution of absent migrants might lead to miscalculating absolute or relative income and remittances. In this section, we simulate migrants' counterfactual income and expenditures in order to calculate net remittances, that is, migrants' net contribution to the household income (Barham and Boucher, 1998; Howell, 2014). To do so, we use the available information from the migrant's rural village and at the same time control for migration self-selection.

The income generating process of an individual within the village is as follows. The individual first decides whether to stay or migrate:

$m_{i}=1\left(g_{i}^{\prime} \psi+\varphi_{i}>0\right)$

where $m_{i}$ is the selection indicator for an individual to migrate. $g_{i}$ is a vector of socio-demographic and economic characteristics affecting migration. As in the previous specification, $\varphi_{\mathrm{i}}$ is the error in the migration equation, assumed to follow a normal distribution with zero mean and unit variance. We then define the selectioncorrected income equation using log household per capita income as follows:

$$
\begin{aligned}
& \log \left(Y_{i}^{*}\right)=x_{i}^{\prime} \mu+u_{i}, \\
& \log \left(Y_{i}\right)=\log \left(Y_{i}^{*}\right) \times m_{i} .
\end{aligned}
$$

\footnotetext{
${ }^{14}$ We have tested additional instruments such as "migration intentions" and "network size in urban areas” in combination with distance and birth order. Results essentially reflect those in Table 6.
} 
Using the conditional expected value of this model, we simulate the counterfactual income of the migrants in our sample:

$\mathrm{E}\left[Y_{i} \mid x_{i}, m_{i}=1\right]=x_{i}^{\prime} \mu+\rho_{u \varphi} \sigma_{u} \frac{\phi\left(g_{i}^{\prime} \psi\right)}{\Phi\left(g_{i}^{\prime} \psi\right)}$

where $\phi$ and $\Phi$ are the probability density and distribution function of the standard normal random variable. The model is estimated simultaneously using a maximum likelihood estimator; $\rho_{u \varphi}=\operatorname{Corr}\left(u_{i}, \varphi_{i}\right)$ is the correlation between the selection and income equations. Predicted values from equation (10) provide an estimate of what the migrant's income would have been had he or she not migrated. We use the identical procedure to obtain the counterfactual expenditures of migrants. In modeling migration we use the same instruments as above, i.e., distance and birth order. To obtain the net remittances, we subtract the difference between the counterfactual income and counterfactual expenditure from the actual remittances. The distribution of net remittances is similar to that of actual remittances, yet a significant portion of net remittances is negative since some migrants contribute more to the household income in the counterfactual situation, i.e., had they not migrated.

As a last step, we calculate the mean net rural income and net remittances within the reference group and use this to estimate the baseline model specification in equation (5). The last column in Table 6 reports the results. Since there are several negative values in the net remittances, in this model we use values in level and not in loghence magnitudes are not directly comparable with the other models in the table. However, the pattern of the estimates remarkably aligns with the baseline, as we find a negative relative income effect and a positive relative remittances effect.

Table 6 about here

\section{Conclusions}

To the best of our knowledge, this is the first paper investigating the effect of remittances on households' relative concerns. Using the Rural to Urban Migration in China survey, we employ a subjective well-being approach on a sample of individuals living in major migrant sending provinces. Our main result suggests that relative concerns matter among rural individuals and households. In particular, the relative 
income effect is negative, implying a status-effect, while the relative remittances effect is positive, implying a signal-effect. The absolute magnitudes of the two effects are very similar. These results are robust with respect to the reference group definition, the measure of relative concerns, and several self-selection issues.

Our study has two major implications. First, we provide a potential explanation of why relative concerns with respect to income are found to be weak or negligible in some developing countries. We show that the effect of overall income depends on its components: the part accruing to remittances and the part rural activities generate. Failing to disentangle these aspects would confound the status- and signal-effects. Second, policy aiming to improve rural households' well-being (e.g., redistributive interventions) should take into account the potential contrasting outcomes in terms of relative concerns with respect to rural income and remittances. 


\section{References}

Acosta, P., C. Calderon, P. Fanjzylber, and H. Lopez (2008). What is the Impact of International Remittances on Poverty and Inequality in Latin America?, World Development 36(1): 89-114.

Akay, A., and P. Martinsson (2011). Does Relative Income Matter for the Very Poor? Evidence from Rural Ethiopia, Economics Letters 110: 213-215.

Akay, A., O. Bargain, and K.F. Zimmermann (2012). Relative Concerns of Rural-toUrban Migrants in China, Journal of Economic Behavior and Organization 81: 421-441.

Akay, A., C. Giulietti, J.D. Robalino, and K.F. Zimmermann (2014). Remittances and well-being among rural-to-urban migrants in China, Review of Economics of the Household 12(3): 517-546.

Akay, A., G. Karabulut, and P. Martinsson (2013). The Effect of Religiosity and Religious Festivals on Positional Concerns: An Experimental Investigation of Ramadan. Applied Economics 45(27): 3914-3921.

Akay, A., P. Martinsson, and H. Medhin (2011). Does Positional Concern Matter in Poor Societies? Evidence from a Survey Experiment in Rural Ethiopia, World Development 40: 428-435.

Akgüc, M., C. Giulietti, and K.F. Zimmermann (2014). The RUMiC Longitudinal Survey: Fostering Research on Labor Markets in China, IZA Journal of Labor and Development 3: 5.

Alpizar, F., F. Carlsson, and O. Johansson-Stenman. (2005). How Much Do We Care about Absolute versus Relative Income and Consumption?, Journal of Economic Behavior and Organization 56: 405-421.

Appleton, S., and L. Song (2008). Life Satisfaction in Urban China: Components and Determinants, World Development 36: 2325-2340.

Barham, B., and S. Boucher (1998). Migration, remittances and inequality: estimating the net effects of migration on income distribution, Journal of Development Economics 55: 307-331.

Biavaschi, C., C. Giulietti, and K.F. Zimmermann (2015). Sibling Influence on the Human Capital of the Left Behind, Journal of Human Capital forthcoming.

Blanchflower, D.G., and A.J. Oswald (2008). Is Well-being U-Shaped over the Life Cycle?, Social Science \& Medicine 66: 1733-1749.

Boyce, C., and A. Wood (2011). Personality and the marginal utility of income: Personality interacts with increases in household income to determine life satisfaction, Journal of Economic Behavior \& Organization 78(1-2): 183-191. 
Bookwalter, J., and D.R. Dalenberg (2009). Relative to What or Whom? The Importance of Norms and Relative Standing, World Development 38: 345-355.

Cai, F., Y. Du, and D. Wang (Eds.) (2011). Zhongguo renkou yu laodong wenti baogao No.12 (Report on China's Population and Labour), Beijing: Shehui kexue wenxian chubanshe.

Carlsson, F., O. Johansson-Stenman, and P. Martinsson (2007). Do You Enjoy Having More than Others? Survey Evidence of Positional Goods, Economica 74: 586-598.

Clark, A., and A. Oswald (1994). Unhappiness and unemployment, Economic Journal 104: 648-659.

Clark, A.E.. and A.J. Oswald (1996). Satisfaction and comparison income, Journal of Public Economics 61: 359-381.

Clark, A., and A. Oswald (2002). A simple statistical method for measuring how life events affect happiness, International Journal of Epidemiology 31(6): 11391144.

Clark, A.E., and C. Senik (2010). Who Compares to Whom? The Anatomy of Income Comparisons in Europe, Economic Journal 120: 573-594.

Clark, A.E., P. Frijters, and M.A. Shields (2008). Relative Income, Happiness, and Utility: An Explanation for the Easterlin Paradox and Other Puzzles, Journal of Economic Literature 46: 95-144.

Dolan, P., T. Peasgood, and M. White (2008). Do We Really Know What Makes Us Happy? A Review of the Economic Literature on the Factors Associated with SWB, Journal of Economic Psychology 29: 94-122.

Duesenberry, James S. (1949). Incomes, Savings and the Theory of Consumer Behavior. Cambridge: University of Harvard Press.

Easterlin, R. (1974). Does economic growth improve the human lot? Some empirical evidence. In David, R. and R. Reder (Eds.) Nations and Households in Economic Growth: Essays in Honor of Moses Abramovitz. New York: Academic Press.

Easterlin, R.A. (1995). Will raising the incomes of all increase the happiness of all?, Journal of Economic Behavior and Organization 27: 35-47.

Ferrer-i-Carbonell, A. (2005). Income and well-being: An empirical analysis of the comparison income effect, Journal of Public Economics 89: 997-1019.

Ferrer-i-Carbonell, A., and P. Frijters (2004). How important is methodology for the estimates of the determinants of happiness?, Economic Journal 114: 641-659.

Frey, B., and A. Stutzer (2002). What can economists learn from happiness research?, 
Journal of Economic literature 40(2): 402-435.

Giulietti, C, J. Wahba, and K.F. Zimmermann (2013). Entrepreneurship of the Left Behind, Research in Labor Economics 37: 65-92.

Goldberg, D. (1978). Manual of the General Health Questionnaire. Windsor, England: NFER Publishing; 1978.

Gong, X., S. Kong, S. Li, and X. Meng (2008). Rural-urban migrants: A driving force for growth, China's Dilemma: Economic Growth. In Song, L., and Thye Woo, W. (Eds.) The Environment and Climate Change. Canberra: Asia Pacific Press, 110-152.

Graham, C. (2005). Insights on development from the economics of happiness, World Bank Research Observer 20(2): 201-232.

Graham, C, and S. Pettinato (2002). Frustrated achievers: winners, losers and subjective well-being in new market economies, Journal of Development Studies 384: 100-140.

Hankins, M. (2008). The factor structure of the twelve item General Health Questionnaire (GHQ-12): the result of negative phrasing? Clinical Practice and Epidemiology in Mental Health 2008, 4:1-8.

Helliwell, J. (2003). How's life? Combining individual and national variables to explain subjective well-being, Economic Modelling 20(2): 331-360.

Hirschman, A., and M. Rothschild (1973): The changing tolerance for income inequality in the course of economic development, Quarterly Journal of Economics 87: 544-565.

Howell, A. (2014). Ethnic Migration, Remittances and Rural Development in China's Least Developed Areas: A Case of 'Immiserizing Growth?’, Working Paper.

Kahneman, D., and R. Sugden (2005). Experienced utility as a standard of policy evaluation, Environmental and Resource Economics 32(1): 161-181.

Kingdon, G., and J. Knight (2006). Subjective well-being poverty versus income poverty and capabilities poverty?, Journal of Development Studies 42(7): 1199-1224.

Kingdon, G., and J. Knight (2007). Community, comparisons and subjective wellbeing in a divided society, Journal of Economic Behavior and Organization 64: 69-90.

Knight J., L. Song, and R. Gunatilaka (2009). SWB and its determinants in rural China, China Economic Review 20: 635-649.

Knight, J. and R. Gunatilaka (2010). Great expectations? The Subjective Well-being of Rural-Urban Migrants in China, World Development 38: 113-124. 
Layard G., G. Mayraz, and S. Nickell (2008). The Marginal Utility of Income, Journal of Public Economics 92: 1846-1857.

Luttmer, E. (2005). Neighbors as negatives: Relative earnings and well-being, Quarterly Journal of Economics 120: 963-1002.

McBride, M. (2001). Relative-income effects on SWB in the cross-section, Journal of Economic Behavior and Organization 45: 251-278.

Neumark, D., and A. Postlewaite (1998). Relative income concerns and the rise in married women's employment, Journal of Public Economics 70: 157-183.

Pouwels, B., J. Siegers, and J.D. Vlasblom (2008). Income, working hours, and happiness, Economics Letters 99(1): 72-74.

Ravillon, M., and M. Lokshin (2000). Who Wants to Redistribute? The Tunnel-Effect in 1990s Russia, Journal of Public Economics 76: 87-104.

Ravillon, M. and M. Lokshin (2002). Self-rated economic welfare in Russia, European-Economic Review 46: 1453-1473.

Senik, C. (2004). When Information Dominates Comparison: A Panel Data Analysis Using Russian Subjective Data, Journal of Public Economics 88: 2099-2123.

Senik, C. (2005). Income distribution and well-being: what can we learn from subjective data?, Journal of Economic Surveys 19: 43-63.

Senik, C. (2008). Ambition and Jealousy. Income Interactions in the "Old Europe" versus the "New Europe" and the United States, Economica 75: 495-513.

Solnick, S., and D. Hemenway (2007). Positional Goods in the United States and China, Journal of Socio-Economics 36: 537-545.

Solnick, S.J., and D. Hemenway (1998). Is more always better?: A survey on positional concerns, Journal of Economic Behavior and Organization 37: 373383.

Stark, O. (2006). Inequality and migration: A behavioral link, Economics Letters 91: $146-152$.

Stark, O., and S. Yitzhaki (1988). Labour migration as a response to relative deprivation, Journal of Population Economics 1(1): 57-70.

Winkelmann, L., and R. Winkelmann (1998). Why are the unemployed so unhappy? Evidence from panel data, Economica 65: 1-15.

Wu, Z. (2008). Relative Income Positions and Labor Migration: A Panel Study Based on a Rural Household Survey in China, Osaka Discussion Papers in Economics and Business 08-24. 


\section{Appendix}

Appendix A. Descriptive Statistics of Control Variables

Whole Sample Households without Remittances

Subjective Well-Being (GHQ 12) Households without Remittances

\begin{tabular}{|c|c|c|c|c|c|c|c|c|c|c|c|}
\hline \multicolumn{4}{|c|}{ Whole Sample } & \multicolumn{4}{|c|}{ Households without Remittances } & \multicolumn{4}{|c|}{ Households with Remittances } \\
\hline \multicolumn{2}{|c|}{ All } & \multicolumn{2}{|c|}{ HH Head } & \multicolumn{2}{|c|}{ All } & \multicolumn{2}{|c|}{ HH Head } & \multicolumn{2}{|c|}{ All } & \multicolumn{2}{|c|}{ HH Head } \\
\hline Mean & SD. & Mean & SD. & Mean & SD. & Mean & SD. & Mean & SD. & Mean & SD. \\
\hline 28.081 & (5.179) & 28.648 & $(4.891)$ & 28.267 & $(5.112)$ & 28.838 & $(4.789)$ & 27.856 & $(5.251)$ & 28.412 & $(5.006)$ \\
\hline 48.106 & (11.029) & 50.874 & $(9.235)$ & 47.494 & (11.467) & 50.301 & $(9.807)$ & 48.845 & $(10.431)$ & 51.585 & $(8.421)$ \\
\hline 0.557 & $(0.497)$ & 0.954 & $(0.209)$ & 0.573 & $(0.495)$ & 0.961 & $(0.193)$ & 0.538 & $(0.499)$ & 0.945 & $(0.227)$ \\
\hline 0.934 & $(0.249)$ & 0.954 & $(0.210)$ & 0.924 & $(0.265)$ & 0.952 & $(0.214)$ & 0.946 & $(0.227)$ & 0.956 & $(0.205)$ \\
\hline 0.491 & $(0.500)$ & 0.497 & $(0.500)$ & 0.495 & $(0.500)$ & 0.499 & $(0.500)$ & 0.487 & $(0.500)$ & 0.494 & $(0.500)$ \\
\hline 0.232 & $(0.422)$ & 0.231 & $(0.421)$ & 0.220 & $(0.415)$ & 0.214 & $(0.410)$ & 0.247 & $(0.431)$ & 0.251 & $(0.434)$ \\
\hline 0.053 & $(0.225)$ & 0.045 & $(0.208)$ & 0.050 & $(0.218)$ & 0.045 & $(0.207)$ & 0.057 & $(0.232)$ & 0.046 & $(0.210)$ \\
\hline 6.742 & (3.065) & 7.279 & (2.629) & 6.964 & (3.122) & 7.442 & (2.698) & 6.476 & $(2.974)$ & 7.077 & (2.527) \\
\hline 0.060 & $(0.238)$ & 0.056 & $(0.230)$ & 0.082 & $(0.274)$ & 0.077 & $(0.267)$ & 0.035 & $(0.183)$ & 0.030 & $(0.170)$ \\
\hline 0.262 & $(0.440)$ & 0.247 & $(0.431)$ & 0.302 & $(0.459)$ & 0.291 & $(0.454)$ & 0.215 & $(0.411)$ & 0.192 & $(0.394)$ \\
\hline 0.402 & $(0.490)$ & 0.423 & $(0.494)$ & 0.392 & $(0.488)$ & 0.421 & $(0.494)$ & 0.415 & $(0.493)$ & 0.426 & $(0.495)$ \\
\hline 0.280 & $(0.449)$ & 0.303 & $(0.459)$ & 0.243 & $(0.429)$ & 0.262 & $(0.440)$ & 0.326 & $(0.469)$ & 0.353 & $(0.478)$ \\
\hline 4.060 & (1.376) & 3.965 & (1.393) & 3.749 & (1.306) & 3.629 & (1.293) & 4.436 & (1.363) & 4.381 & $(1.401)$ \\
\hline 0.522 & $(0.500)$ & 1.000 & $(0.000)$ & 0.528 & $(0.499)$ & 1.000 & $(0.000)$ & 0.513 & $(0.500)$ & 1.000 & $(0.000)$ \\
\hline 0.374 & $(0.484)$ & 0.000 & $(0.000)$ & 0.362 & $(0.481)$ & 0.000 & $(0.000)$ & 0.389 & $(0.488)$ & 0.000 & $(0.000)$ \\
\hline 0.083 & $(0.276)$ & 0.000 & $(0.000)$ & 0.094 & $(0.292)$ & 0.000 & $(0.000)$ & 0.070 & $(0.255)$ & 0.000 & $(0.000)$ \\
\hline 0.018 & $(0.132)$ & 0.023 & $(0.151)$ & 0.005 & $(0.073)$ & 0.007 & $(0.083)$ & 0.032 & $(0.177)$ & 0.044 & $(0.205)$ \\
\hline 0.044 & $(0.206)$ & 0.000 & $(0.000)$ & 0.010 & $(0.101)$ & 0.000 & $(0.000)$ & 0.086 & $(0.280)$ & 0.000 & $(0.000)$ \\
\hline 0.187 & $(0.390)$ & 0.200 & $(0.400)$ & 0.136 & $(0.342)$ & 0.142 & $(0.349)$ & 0.250 & $(0.433)$ & 0.272 & $(0.445)$ \\
\hline 0.158 & $(0.365)$ & 0.175 & $(0.380)$ & 0.049 & $(0.215)$ & 0.057 & $(0.232)$ & 0.290 & $(0.454)$ & 0.322 & $(0.467)$ \\
\hline 0.023 & $(0.150)$ & 0.022 & $(0.147)$ & 0.011 & $(0.107)$ & 0.010 & $(0.100)$ & 0.037 & $(0.188)$ & 0.037 & $(0.189)$ \\
\hline 0.148 & $(0.356)$ & 0.181 & $(0.385)$ & 0.134 & $(0.341)$ & 0.166 & $(0.372)$ & 0.166 & $(0.372)$ & 0.200 & $(0.400)$ \\
\hline 0.612 & $(0.487)$ & 0.609 & $(0.488)$ & 0.799 & $(0.401)$ & 0.793 & $(0.405)$ & 0.386 & $(0.487)$ & 0.382 & $(0.486)$ \\
\hline 0.206 & $(0.405)$ & 0.202 & $(0.401)$ & 0.145 & $(0.352)$ & 0.145 & $(0.352)$ & 0.280 & $(0.449)$ & 0.272 & $(0.445)$ \\
\hline 0.126 & $(0.332)$ & 0.133 & (0.339) & 0.044 & $(0.205)$ & 0.049 & $(0.217)$ & 0.226 & $(0.418)$ & 0.236 & $(0.425)$ \\
\hline 0.055 & $(0.229)$ & 0.056 & $(0.231)$ & 0.012 & $(0.108)$ & 0.013 & $(0.112)$ & 0.108 & $(0.310)$ & 0.110 & $(0.314)$ \\
\hline 3.823 & $(7.201)$ & 3.781 & (7.258) & & & & & 8.432 & (8.689) & 8.471 & (8.850) \\
\hline 3.365 & $(5.220)$ & 3.357 & (5.246) & & & & & 6.217 & $(6.725)$ & 6.282 & (6.799) \\
\hline 22.363 & (23.895) & 22.203 & (24.652) & 27.370 & (29.048) & 26.785 & (30.170) & 16.326 & (13.244) & 16.519 & (13.200) \\
\hline 14.962 & (15.429) & 15.351 & (16.520) & 17.727 & (18.362) & 18.050 & (19.789) & 11.628 & (9.914) & 12.003 & (10.272) \\
\hline 0.225 & $(0.418)$ & 0.247 & $(0.431)$ & 0.281 & $(0.449)$ & 0.295 & $(0.456)$ & 0.158 & $(0.364)$ & 0.188 & $(0.391)$ \\
\hline 0.072 & $(0.258)$ & 0.094 & $(0.291)$ & 0.096 & $(0.294)$ & 0.120 & $(0.325)$ & 0.043 & $(0.203)$ & 0.061 & $(0.239)$ \\
\hline 11624 & & 6063 & & 6354 & & 3357 & & 5270 & & 2706 & \\
\hline
\end{tabular}

Age

(1)

Good Health

Average Health

Poor Health

Years of Education

Urban Hukou

One Child

Two Children

More than Two Children

Number HH Members

Relationship to Head: Head

Relationship to Head: Spouse

Relationship to Head: Child

Spouse is a Migrant

HH Head is a Migrant

One Child is a Migrant

Two Children are Migrants

Other HH Member is Migrant

Migrated in the Past

No Migrants in $\mathrm{HH}$

One Migrant in $\mathrm{HH}$

Two Migrants in $\mathrm{HH}$

More than Two Migrants in $\mathrm{HH}$

Remittances (1000 CNY)

Remittances per Capita (1000 CNY)

Household Income (1000 CNY)

Household per C. Income (1000 CNY)

Wage Employment

Self-employment

6063

Source: RUMiC 2008. Notes: Standard deviations in parentheses. Income and remittances are in 1,000 CNY. 


\section{Appendix B: General Health Questionnaire (GHQ 12)}

\section{1- When you are doing something do you find that}

(1) Can concentrate; (2) Attention occasionally diverted; (3) Attention sometimes diverted;

(4) Attention frequently diverted, cannot concentrate

2- Do you often lose sleep over worry?

(1) Not at all; (2) Occasionally; (3) Fairly often; (4) Very often

3 - Can you play useful part in things?

(1) Always can; (2) Can play some positive roles; (3) Can play positive roles poorly;

(4) Cannot play a positive role

\section{4- Are you capable of making decisions?}

(1) Always have own opinions; (2) Sometimes have own opinions; (3) Do not have many

own opinions; 4) Do not have any personal opinion at al

5- Are you constantly under strain?

(1) Never; (2) Sometimes; (3) Fairly often; (4) Very often

6- Do you feel you couldn't overcome difficulties?

(1) Never; (2) Sometimes; (3) Fairly often; (4) Very often
7- Are you able to enjoy day-to-day activities?

(1) Very interesting; (2) Fairly interesting; (3) Not very interesting;

(4) Not interesting at al

8- Are you able to face problems?

(1) Never; (2) Seldom; (3) Sometimes; (4) Always

\section{9- Do you feel depressed?}

(1) Not at all; (2) A little bit; (3) Fairly seriously;

(4) Very seriously

10- Do you always lack confidence?

(1) Not at all; (2) A little bit; (3) Fairly seriously;

(4) Very seriously

11- Do you often think that you have no value?

(1) Not at all; (2) A little bit; (3) Fairly seriously; (4) Very seriously

12- Are you happy when you consider each aspect of your life?

(1) Very happy; (2) Fairly happy; (3) Not very happy; (4) Not happy at all

Source: RUMiC 2007. See Goldberg D (1978) for questions and use of the GHQ. 
Figures and Tables

Figure 1. Distribution of SWB

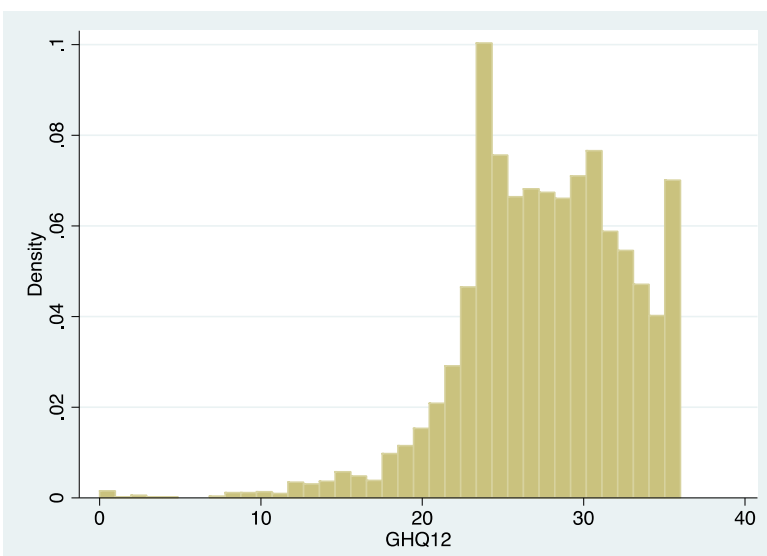

a) Individuals who receive remittances

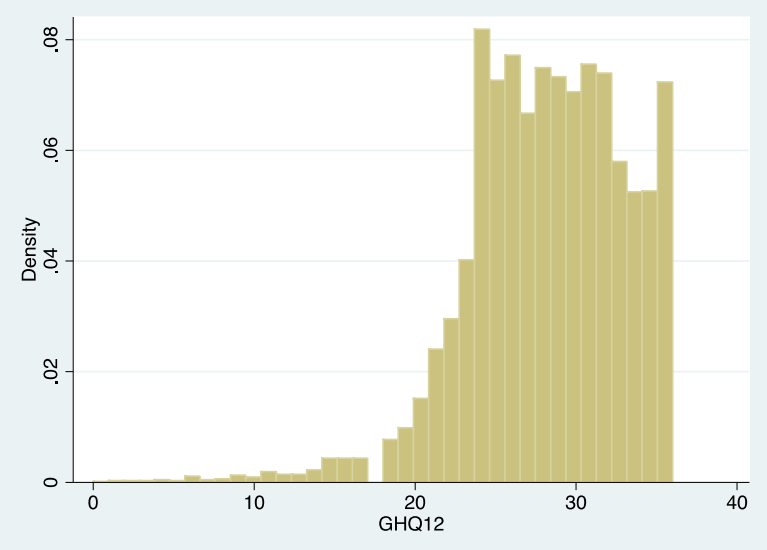

b) Individuals who do not receive remittances

Source: RUMiC 2007. Notes: GHQ-12 index obtained by summing the answers to the GHQ questionnaire. 
Figure 2. Counties sampled by RUMiC

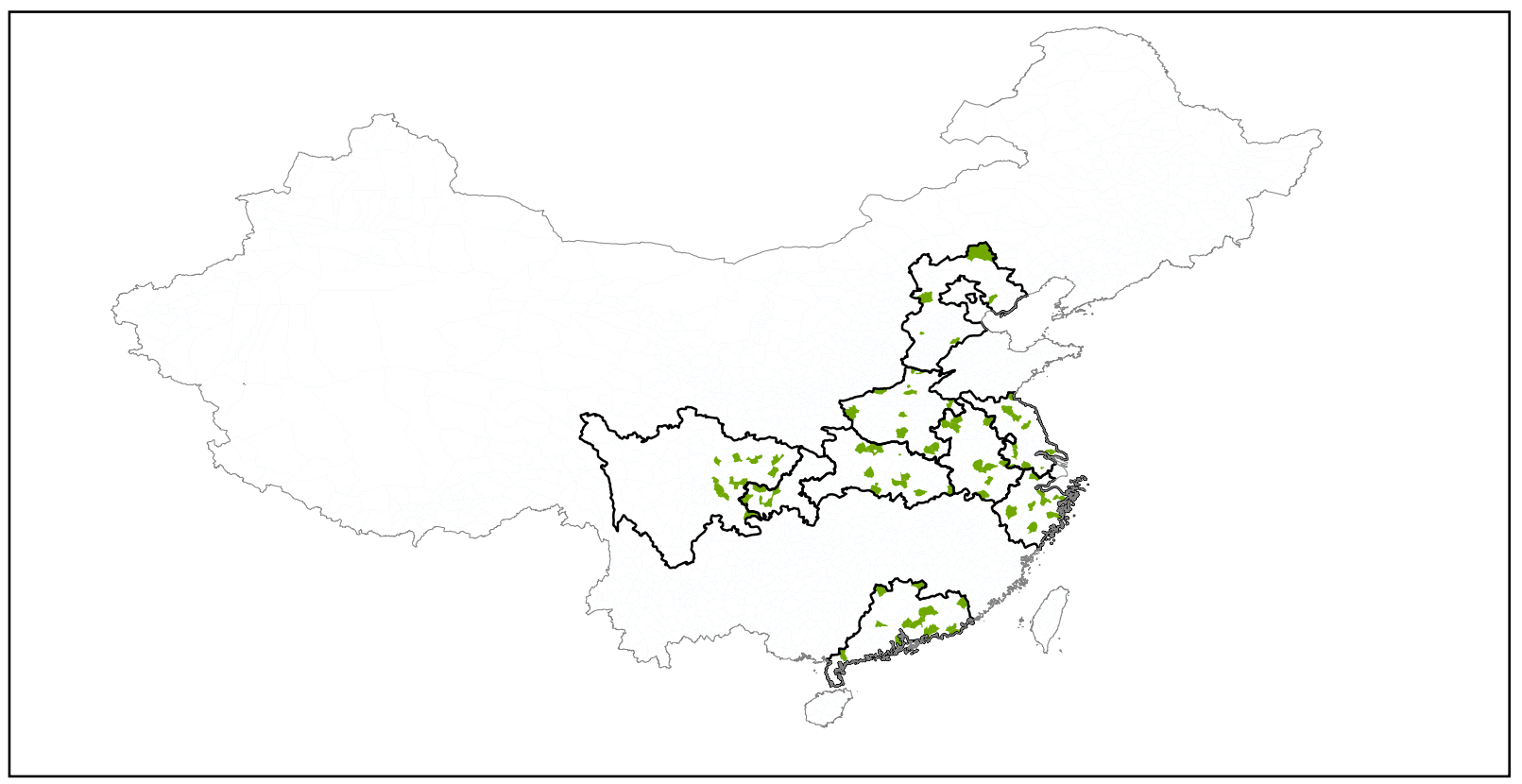

Note: The nine countries are Anhui, Chongqing, Guangdong, Hebei, Henan, Hubei, Jiangsu, Sichuan and Zhejiang. 
Table 1. Descriptive Statistics

\begin{tabular}{|c|c|c|c|c|c|c|c|c|c|c|c|c|}
\hline & \multicolumn{4}{|c|}{ Whole Sample } & \multicolumn{4}{|c|}{ Households without Remittances } & \multicolumn{4}{|c|}{ Households with Remittances } \\
\hline & \multicolumn{2}{|c|}{ All } & \multicolumn{2}{|c|}{ HH Head } & \multicolumn{2}{|c|}{ All } & \multicolumn{2}{|c|}{ HH Head } & \multicolumn{2}{|c|}{ All } & \multicolumn{2}{|c|}{ HH Head } \\
\hline & Mean & SD. & Mean & SD. & Mean & SD. & Mean & SD. & Mean & SD. & Mean & SD. \\
\hline Remittances & 3.823 & $(7.201)$ & 3.781 & $(7.258)$ & & & & & 8.432 & (8.689) & 8.471 & $(8.850)$ \\
\hline Remittances per Capita & 3.365 & $(5.22)$ & 3.357 & $(5.246)$ & & & & & 6.217 & $(6.725)$ & 6.282 & (6.799) \\
\hline Household Income & 22.363 & $(23.895)$ & 22.203 & $(24.652)$ & 27.370 & $(29.048)$ & 26.785 & $(30.170)$ & 16.326 & (13.244) & 16.519 & $(13.200)$ \\
\hline Household per Capita Income & 14.962 & $(15.429)$ & 15.351 & $(16.520)$ & 17.727 & $(18.362)$ & 18.050 & (19.789) & 11.628 & (9.914) & 12.003 & (10.272) \\
\hline Observations & 11624 & & 6063 & & 6354 & & 3357 & & 5270 & & 2706 & \\
\hline
\end{tabular}

Source: RUMiC 2008. Notes: Standard deviations in parentheses. Income and remittances are in 1,000 CNY. 
Table 2. Determinants of Subjective Well-Being in Rural China

\begin{tabular}{|c|c|c|c|c|c|c|}
\hline & \multicolumn{2}{|c|}{ Whole sample } & \multicolumn{2}{|c|}{ HH with remittances } & \multicolumn{2}{|c|}{ HH without remittances } \\
\hline & All & HH head & All & HH head & All & HH head \\
\hline \multicolumn{7}{|l|}{ Economic Characteristics } \\
\hline \multirow[t]{2}{*}{ Log HH Income per Capita } & $0.210 * *$ & $0.256^{* * *}$ & 0.206 & $0.293^{* *}$ & $0.237 * *$ & $0.243^{* *}$ \\
\hline & $(0.084)$ & $(0.091)$ & $(0.135)$ & $(0.148)$ & $(0.112)$ & $(0.119)$ \\
\hline \multirow[t]{2}{*}{ Log Remittances per Capita } & $0.175^{* *}$ & $0.176 * *$ & $0.198 *$ & $0.293 * *$ & & \\
\hline & $(0.068)$ & $(0.076)$ & $(0.111)$ & $(0.123)$ & & \\
\hline \multirow[t]{2}{*}{ Farmer } & $1.111 * * *$ & $1.011^{* * *}$ & 0.086 & 0.523 & $1.568 * * *$ & $1.147 * * *$ \\
\hline & $(0.270)$ & $(0.356)$ & $(0.480)$ & $(0.615)$ & $(0.323)$ & $(0.426)$ \\
\hline \multirow[t]{2}{*}{ Self-employed (D) } & $1.129 * * *$ & $1.232 * * *$ & 0.241 & 0.739 & $1.502^{* * *}$ & $1.357 * * *$ \\
\hline & $(0.312)$ & $(0.382)$ & $(0.566)$ & $(0.661)$ & $(0.371)$ & $(0.456)$ \\
\hline \multirow[t]{2}{*}{ Farmer (D) } & $0.685^{* * *}$ & $0.618 * *$ & $0.783^{* * *}$ & $1.173^{* * *}$ & $0.553 * * *$ & 0.186 \\
\hline & $(0.165)$ & (0.269) & $(0.265)$ & $(0.443)$ & $(0.205)$ & $(0.327)$ \\
\hline \multirow[t]{2}{*}{ Hours of Work } & $-0.008 *$ & -0.007 & 0.006 & 0.009 & $-0.014 * * *$ & $-0.015 * * *$ \\
\hline & $(0.004)$ & $(0.005)$ & $(0.008)$ & $(0.009)$ & $(0.005)$ & $(0.006)$ \\
\hline \multirow[t]{2}{*}{ Land Size (Mu) } & $-0.022 *$ & -0.023 & -0.038 & $-0.053 * *$ & -0.017 & -0.011 \\
\hline & $(0.014)$ & $(0.015)$ & $(0.023)$ & $(0.025)$ & $(0.016)$ & $(0.017)$ \\
\hline \multirow[t]{2}{*}{ House Size $\left(\mathrm{m}^{2}\right)$} & $0.507^{* * *} *$ & $0.473^{* * *}$ & 0.360 & $0.516^{* *}$ & $0.530 * * *$ & $0.410^{* *}$ \\
\hline & $(0.140)$ & $(0.151)$ & $(0.227)$ & $(0.253)$ & $(0.177)$ & $(0.190)$ \\
\hline \multirow[t]{2}{*}{ House Value (1000 CNY) } & 0.078 & 0.125 & 0.111 & 0.104 & 0.102 & 0.164 \\
\hline & $(0.074)$ & $(0.080)$ & $(0.113)$ & $(0.124)$ & $(0.097)$ & $(0.104)$ \\
\hline \multicolumn{7}{|c|}{ Socio-demographic Characteristics } \\
\hline \multirow[t]{2}{*}{ Age } & $-0.118 * * *$ & -0.009 & -0.088 & -0.002 & $-0.131 * *$ & -0.008 \\
\hline & $(0.043)$ & $(0.062)$ & $(0.069)$ & $(0.106)$ & $(0.054)$ & $(0.079)$ \\
\hline \multirow[t]{2}{*}{ Age squared } & $0.001 * *$ & 0.000 & 0.001 & 0.000 & $0.001 * *$ & 0.000 \\
\hline & $(0.000)$ & $(0.001)$ & $(0.001)$ & $(0.001)$ & $(0.001)$ & $(0.001)$ \\
\hline \multirow[t]{2}{*}{ Male } & $0.756 * * *$ & $0.901^{* * *}$ & $0.809 * * *$ & $1.144^{* *}$ & $0.734 * * *$ & 0.670 \\
\hline & $(0.191)$ & $(0.325)$ & $(0.286)$ & $(0.444)$ & $(0.258)$ & $(0.479)$ \\
\hline \multirow[t]{2}{*}{ Married } & $1.173^{* * *}$ & $1.538 * * *$ & $1.233^{* * *}$ & $1.579 * * *$ & $1.148 * * *$ & $1.529 * * *$ \\
\hline & $(0.255)$ & $(0.315)$ & $(0.389)$ & $(0.474)$ & $(0.331)$ & $(0.418)$ \\
\hline \multirow[t]{2}{*}{ Good Health } & $-2.228 * * *$ & $-2.012 * * *$ & $-2.262 * * *$ & $-2.317 * * *$ & $-2.165 * * *$ & $-1.797 * * *$ \\
\hline & $(0.121)$ & $(0.140)$ & $(0.189)$ & $(0.221)$ & $(0.158)$ & $(0.181)$ \\
\hline \multirow[t]{2}{*}{ Average Health } & $-3.728 * * *$ & $-3.349 * * *$ & $-3.602 * * *$ & $-3.368 * * *$ & $-3.803 * * *$ & $-3.389 * * *$ \\
\hline & $(0.154)$ & $(0.179)$ & $(0.227)$ & $(0.263)$ & $(0.211)$ & $(0.246)$ \\
\hline \multirow[t]{2}{*}{ Poor Health } & $-8.143^{* * *}$ & $-7.216 * * *$ & $-8.052 * * *$ & $-7.374 * * *$ & $-8.174 * * *$ & $-7.043 * * *$ \\
\hline & $(0.316)$ & $(0.440)$ & $(0.471)$ & $(0.698)$ & $(0.422)$ & $(0.553)$ \\
\hline \multirow[t]{2}{*}{ Years of Education } & $0.166^{* * *}$ & $0.140 * * *$ & $0.185 * * *$ & $0.131^{* * *}$ & $0.142 * * *$ & $0.139 * * *$ \\
\hline & $(0.018)$ & $(0.024)$ & $(0.028)$ & $(0.039)$ & $(0.024)$ & $(0.031)$ \\
\hline
\end{tabular}




\begin{tabular}{|c|c|c|c|c|c|c|}
\hline Height (cm) & $\begin{array}{c}0.014 \\
(0.010)\end{array}$ & $\begin{array}{c}-0.002 \\
(0.013)\end{array}$ & $\begin{array}{c}0.020 \\
(0.015)\end{array}$ & $\begin{array}{c}0.005 \\
(0.020)\end{array}$ & $\begin{array}{c}0.008 \\
(0.013)\end{array}$ & $\begin{array}{c}-0.006 \\
(0.017)\end{array}$ \\
\hline \multirow[t]{2}{*}{ Weight (kg) } & $0.014 * *$ & $0.019 * *$ & 0.007 & 0.008 & $0.023^{* * *}$ & $0.029 * *$ \\
\hline & $(0.007)$ & $(0.009)$ & $(0.010)$ & $(0.013)$ & $(0.009)$ & $(0.011)$ \\
\hline \multirow[t]{2}{*}{ Urban Hukou } & 0.113 & 0.408 & $0.841 * *$ & $1.845^{* * *}$ & -0.076 & 0.001 \\
\hline & $(0.217)$ & $(0.250)$ & $(0.395)$ & $(0.484)$ & $(0.256)$ & $(0.287)$ \\
\hline \multirow[t]{2}{*}{ One Child } & 0.086 & $0.665 *$ & 0.515 & 1.036 & -0.296 & 0.358 \\
\hline & $(0.310)$ & $(0.388)$ & $(0.533)$ & $(0.648)$ & $(0.367)$ & $(0.470)$ \\
\hline \multirow[t]{2}{*}{ Two Children } & 0.181 & 0.564 & 0.396 & 0.686 & 0.044 & 0.518 \\
\hline & $(0.315)$ & $(0.382)$ & $(0.542)$ & $(0.629)$ & $(0.370)$ & $(0.466)$ \\
\hline \multirow[t]{2}{*}{ More than Two Children } & 0.079 & 0.559 & 0.515 & 0.949 & -0.297 & 0.268 \\
\hline & $(0.329)$ & $(0.398)$ & $(0.558)$ & $(0.652)$ & $(0.391)$ & $(0.488)$ \\
\hline \# HH Members & $0.232 * * *$ & $0.226 * * *$ & $0.307 * * *$ & $0.386 * * *$ & $0.198^{* * *}$ & $0.147 * *$ \\
\hline \multicolumn{7}{|l|}{ Migration Characteristics } \\
\hline \multirow[t]{2}{*}{ HH Head Migrant } & 0.086 & & 0.317 & & -0.234 & \\
\hline & $(0.261)$ & & $(0.300)$ & & $(0.715)$ & \\
\hline \multirow[t]{2}{*}{ Spouse Migrant } & -0.166 & -0.277 & -0.033 & -0.182 & 0.237 & -0.119 \\
\hline & $(0.414)$ & $(0.394)$ & $(0.465)$ & $(0.447)$ & $(0.905)$ & $(0.879)$ \\
\hline \multirow[t]{2}{*}{ Has Migrated before 2007} & -0.076 & -0.228 & -0.056 & -0.300 & -0.063 & -0.186 \\
\hline & $(0.136)$ & $(0.159)$ & $(0.202)$ & $(0.250)$ & $(0.187)$ & $(0.207)$ \\
\hline \multirow[t]{2}{*}{ One Migrant in $\mathrm{HH}$} & $-0.644 * * *$ & $-0.711 * * *$ & $-0.928 * * *$ & $-0.887 * * *$ & $-0.561 * * *$ & $-0.660 * * *$ \\
\hline & $(0.144)$ & $(0.158)$ & $(0.218)$ & $(0.238)$ & $(0.195)$ & $(0.219)$ \\
\hline \multirow[t]{2}{*}{ Two Migrants in $\mathrm{HH}$} & $-0.550 * * *$ & $-0.566 * * *$ & $-0.977 * * *$ & $-0.986 * * *$ & -0.008 & 0.035 \\
\hline & $(0.195)$ & $(0.213)$ & $(0.259)$ & $(0.281)$ & $(0.329)$ & $(0.362)$ \\
\hline \multirow[t]{2}{*}{ Three or More Migrants in $\mathrm{HH}$} & $-1.136 * * *$ & $-1.174 * * *$ & $-1.665 * * *$ & $-1.810^{* * *}$ & $-1.369 * *$ & $-1.462 * *$ \\
\hline & $(0.291)$ & $(0.331)$ & $(0.372)$ & $(0.420)$ & $(0.612)$ & $(0.700)$ \\
\hline \multirow[t]{2}{*}{ Constant } & $24.377 * * *$ & $22.707 * * *$ & $22.072^{* * *}$ & $20.442 * * *$ & $25.524 * * *$ & $23.798 * * *$ \\
\hline & $(1.872)$ & $(2.564)$ & $(3.005)$ & $(4.172)$ & $(2.401)$ & $(3.284)$ \\
\hline R-squared & 0.234 & 0.191 & 0.217 & 0.181 & 0.260 & 0.214 \\
\hline Observations & 11624 & 6063 & 5270 & 2706 & 6354 & 3357 \\
\hline
\end{tabular}

Source: RUMiC 2008. Notes: Models estimated using OLS. $* * * / * * *$ indicate significance at the $10 \%, 5 \%, 1 \%$ level. Robust standard errors clustered at the household level are shown in parentheses. (D) indicates dummy variables. The model includes indicators for the 10 provinces (estimates are omitted). Per capita income and remittances are calculated using the modified OECD equivalence scale, which uses the following weights: 0.5 for each adult at home and 0.3 for children. 
Table 3: Relative Concerns in Rural China with Alternative Model Specifications and Reference Groups

Baseline

Total $\mathrm{HH}$ income $(\mathrm{a})$

Mean HH Income in reference group

R-Squared

Observations

\begin{tabular}{ccc}
\multicolumn{3}{c}{ Baseline } \\
Income & $\begin{array}{c}\text { Income per } \\
\text { Capita }\end{array}$ & $\begin{array}{c}\text { Log Income } \\
\text { per Capita }\end{array}$ \\
\hline I & II & III \\
\hline $0.007 * * *$ & $0.015^{* * *}$ & $0.369 * * *$ \\
$(0.003)$ & $(0.004)$ & $(0.100)$ \\
0.001 & -0.014 & $-0.504^{* *}$ \\
$(0.009)$ & $(0.015)$ & $(0.247)$ \\
0.233 & 0.234 & 0.234 \\
11624 & 11624 & 11624
\end{tabular}

Alternative Reference Groups

\begin{tabular}{ccc}
\hline \multicolumn{3}{c}{ Alternative Reference Groups } \\
Village & $\begin{array}{c}\text { County }+ \\
\text { Wageworker }\end{array}$ & $\begin{array}{c}\text { County + Age } \\
<40\end{array}$ \\
\hline IV & $\mathrm{V}$ & VI \\
\hline $0.510^{* * *}$ & $0.384^{* * *}$ & $0.349 * * *$ \\
$(0.111)$ & $(0.101)$ & $(0.100)$ \\
$-0.631^{* * *}$ & $-0.594^{* *}$ & -0.335 \\
$(0.169)$ & $(0.240)$ & $(0.239)$ \\
0.235 & 0.234 & 0.234 \\
11624 & 11624 & 11624
\end{tabular}

Source: RUMiC 2008. Notes: Models estimated using OLS. */**/*** indicate significance at the $10 \%$, 5\%, 1\% level. Robust standard errors clustered at the household level are shown in parentheses. Income is measured in 1,000 CNY. Per capita income is calculated using the modified OECD equivalence scale, which uses the following weights: 0.5 for each adult at home and 0.3 for children. 
Table 4: Estimating Relative Remittances: Baseline Estimates, Remittance Receivers, Shifts in Income Rank and Income Inequality

\begin{tabular}{|c|c|c|c|c|c|c|c|c|}
\hline & \multicolumn{2}{|c|}{ Baseline } & \multicolumn{2}{|c|}{ Remittance Receivers } & \multicolumn{3}{|c|}{ Reference Groups } & \multirow{2}{*}{$\begin{array}{c}\text { Inequality } \\
\\
\text { Income } \\
\text { Inequality in } \\
\text { Reference } \\
\text { Groups }\end{array}$} \\
\hline & $\begin{array}{l}\text { Whole } \\
\text { Sample }\end{array}$ & $\begin{array}{l}\text { Only HH } \\
\text { Heads }\end{array}$ & $\begin{array}{c}\text { HH with } \\
\text { Remittances }\end{array}$ & $\begin{array}{l}\text { HH without } \\
\text { Remittances }\end{array}$ & $\begin{array}{c}\text { Reference } \\
\text { Group: } \\
\text { County + } \\
\text { Wage } \\
\text { Workers }\end{array}$ & $\begin{array}{c}\text { Reference } \\
\text { Group: } \\
\text { County }+ \\
\text { age }<40\end{array}$ & $\begin{array}{c}\text { Reference } \\
\text { Group: } \\
\text { County + HH } \\
\text { with Migrants }\end{array}$ & \\
\hline & $\mathrm{I}$ & II & III & IV & $\mathrm{V}$ & VI & VII & VIII \\
\hline Log HH income pc TEST & $\begin{array}{l}0.340^{* * *} \\
(0.089)\end{array}$ & $\begin{array}{l}0.375^{* * *} \\
(0.097)\end{array}$ & $\begin{array}{c}0.269 * \\
(0.144)\end{array}$ & $\begin{array}{l}0.406^{* * *} \\
(0.119)\end{array}$ & $\begin{array}{l}0.353^{* * *} \\
(0.090)\end{array}$ & $\begin{array}{l}0.331 * * * \\
(0.089)\end{array}$ & $\begin{array}{l}0.285^{* * *} \\
(0.090)\end{array}$ & $\begin{array}{l}0.342 * * * \\
(0.089)\end{array}$ \\
\hline Mean Log HH income pc in reference group & $\begin{array}{l}-0.840 * * * \\
(0.219)\end{array}$ & $\begin{array}{l}-0.709 * * * \\
(0.238)\end{array}$ & $\begin{array}{l}-0.403 \\
(0.405)\end{array}$ & $\begin{array}{l}-1.188 * * * \\
(0.263)\end{array}$ & $\begin{array}{l}-0.884 * * * \\
(0.212)\end{array}$ & $\begin{array}{l}-0.755^{* * *} \\
(0.214)\end{array}$ & $\begin{array}{l}-0.423^{* *} \\
(0.210)\end{array}$ & $\begin{array}{l}-0.837 * * * \\
(0.220)\end{array}$ \\
\hline Log remittances pc & $\begin{array}{c}0.07 \\
(0.072)\end{array}$ & $\begin{array}{c}0.067 \\
(0.079)\end{array}$ & $\begin{array}{c}0.162 \\
(0.112)\end{array}$ & & $\begin{array}{c}0.073 \\
(0.072)\end{array}$ & $\begin{array}{c}0.052 \\
(0.072)\end{array}$ & $\begin{array}{c}-0.011 \\
(0.074)\end{array}$ & $\begin{array}{c}0.067 \\
(0.072)\end{array}$ \\
\hline Mean Log remittances pc in reference group & $\begin{array}{l}0.873^{* * *} \\
(0.186)\end{array}$ & $\begin{array}{l}0.902 * * * \\
(0.200)\end{array}$ & $\begin{array}{l}1.062^{* * *} \\
(0.303)\end{array}$ & $\begin{array}{l}0.530^{* *} \\
(0.259)\end{array}$ & $\begin{array}{l}0.810^{* * *} \\
(0.183)\end{array}$ & $\begin{array}{l}0.921^{* * *} \\
(0.169)\end{array}$ & $\begin{array}{l}1.097 * * * \\
(0.181)\end{array}$ & $\begin{array}{l}0.804^{* * *} \\
(0.198)\end{array}$ \\
\hline Change in income inequality due to remittances & & & & & & & & $\begin{array}{c}-1.728 \\
(1.417)\end{array}$ \\
\hline R-squared & 0.238 & 0.196 & 0.221 & 0.266 & 0.238 & 0.239 & 0.239 & 0.239 \\
\hline Observations & 11624 & 6063 & 5270 & 6354 & 11624 & 11624 & 11624 & 11624 \\
\hline
\end{tabular}

Source: RUMiC 2008. Notes: Models estimated using OLS. */**/*** indicate significance at the $10 \%, 5 \%$, $1 \%$ level. Robust standard errors clustered at the household level are shown in parentheses. Income is measured in 1,000 CNY. Per capita income is calculated using the modified OECD equivalence scale, which uses the following weights: 0.5 for each adult at home and 0.3 for children. Income inequality is measured using the GINI coefficient calculated at the county level. 
Table 5: Heterogeneity

Economic Activity and Income Distribution

\begin{tabular}{|c|c|c|c|c|c|c|c|c|c|c|}
\hline & \multicolumn{2}{|c|}{ Wage earners } & \multicolumn{2}{|c|}{ Farmers } & \multicolumn{2}{|c|}{$\begin{array}{c}\% \text { of Wageworkers in county } \\
\text { above median }\end{array}$} & \multicolumn{2}{|c|}{ Relatively rich county } & \multicolumn{2}{|c|}{$\begin{array}{c}\text { Remittances decreased county } \\
\text { inequality }\end{array}$} \\
\hline & $\mathrm{D}=1$ & $\mathrm{D}=0$ & $\mathrm{D}=1$ & $\mathrm{D}=0$ & $\mathrm{D}=1$ & $\mathrm{D}=0$ & $\mathrm{D}=1$ & $\mathrm{D}=0$ & $\mathrm{D}=1$ & $\mathrm{D}=0$ \\
\hline \multirow[t]{2}{*}{ Log HH income pc } & $0.373^{* *}$ & $0.323 * * *$ & $0.262^{* *}$ & $0.447^{* * *}$ & $0.534^{* * *}$ & 0.152 & $0.442^{* * *}$ & $0.242^{* *}$ & $0.299 * * *$ & $0.389^{* * *}$ \\
\hline & $(0.162)$ & $(0.096)$ & $(0.111)$ & $(0.121)$ & $(0.117)$ & $(0.122)$ & $(0.117)$ & $(0.122)$ & $(0.115)$ & $(0.123)$ \\
\hline \multirow[t]{2}{*}{ County mean Log $\mathrm{HH}$ income pc } & $-0.781^{* *}$ & $-0.880 * * *$ & $-1.013^{* * *}$ & $-0.790 * * *$ & $-1.410^{* * *}$ & $-0.717^{* *}$ & $-1.511^{* * *}$ & -0.092 & $-0.616^{* *}$ & $-1.090 * * *$ \\
\hline & $(0.353)$ & $(0.239)$ & $(0.282)$ & $(0.278)$ & $(0.366)$ & $(0.343)$ & $(0.461)$ & $(0.405)$ & $(0.285)$ & $(0.308)$ \\
\hline \multirow[t]{2}{*}{ Log remittances pc } & -0.103 & 0.121 & 0.016 & 0.147 & 0.101 & 0.059 & 0.074 & 0.072 & 0.050 & 0.090 \\
\hline & $(0.120)$ & $(0.079)$ & $(0.086)$ & $(0.098)$ & $(0.095)$ & $(0.094)$ & $(0.098)$ & $(0.091)$ & $(0.092)$ & $(0.098)$ \\
\hline \multirow[t]{2}{*}{ County mean Log remittances pc } & $0.651^{* *}$ & $0.910 * * *$ & $1.247^{* * *}$ & 0.359 & $0.662 * *$ & $0.975 * * *$ & $0.695^{* *}$ & $0.883^{* * *}$ & $0.872 * * *$ & $0.812^{* * *}$ \\
\hline & $(0.325)$ & $(0.204)$ & $(0.226)$ & $(0.266)$ & $(0.326)$ & $(0.235)$ & $(0.282)$ & $(0.286)$ & $(0.251)$ & $(0.293)$ \\
\hline
\end{tabular}

Migration Intensity, Experience and Individual Characteristics

\begin{tabular}{|c|c|c|c|c|c|c|c|c|c|c|}
\hline & \multicolumn{2}{|c|}{ HH without migrants } & \multicolumn{2}{|c|}{$\begin{array}{l}\text { County ratio of migrants } \\
\text { above median }\end{array}$} & \multicolumn{2}{|c|}{ Migrated in the past } & \multicolumn{2}{|c|}{ Older than 40 years old } & \multicolumn{2}{|c|}{ Education above median } \\
\hline & $\mathrm{D}=1$ & $\mathrm{D}=0$ & $\mathrm{D}=1$ & $\mathrm{D}=0$ & $\mathrm{D}=1$ & $\mathrm{D}=0$ & $\mathrm{D}=1$ & $\mathrm{D}=0$ & $\mathrm{D}=1$ & $\mathrm{D}=0$ \\
\hline Log HH income pc & $0.428 * * *$ & $0.248 *$ & $0.298 * *$ & $0.364^{* * *}$ & $0.502^{* * *}$ & $0.305^{* * *}$ & $0.419^{* * *}$ & 0.147 & $0.224 *$ & $0.406^{* * *}$ \\
\hline \multirow[t]{2}{*}{ County mean Log HH pc income } & $-1.080^{* * *}$ & -0.303 & -0.225 & $-1.121^{* * *}$ & $-0.992 * *$ & $-0.809 * * *$ & $-0.547 * *$ & $-1.568 * * *$ & $-0.920 * * *$ & $-0.808 * * *$ \\
\hline & $(0.256)$ & $(0.350)$ & $(0.408)$ & $(0.251)$ & $(0.433)$ & $(0.232)$ & $(0.239)$ & $(0.339)$ & $(0.303)$ & $(0.250)$ \\
\hline Log remittances pc & $0.250^{* *}$ & -0.096 & -0.025 & 0.144 & 0.060 & 0.077 & 0.044 & 0.100 & 0.012 & 0.093 \\
\hline \multirow[t]{2}{*}{ County mean Log remittances pc } & $0.455^{*}$ & $1.408 * * *$ & $1.632 * * *$ & 0.521 & $0.894^{* * *}$ & $0.864 * * *$ & $1.101^{* * *}$ & 0.185 & $0.937 * * *$ & $0.845^{* * *}$ \\
\hline & $(0.257)$ & $(0.245)$ & $(0.264)$ & $(0.353)$ & $(0.345)$ & (0.199) & (0.194) & $(0.370)$ & $(0.260)$ & $(0.222)$ \\
\hline
\end{tabular}

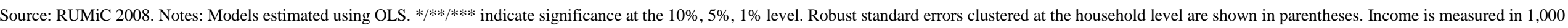

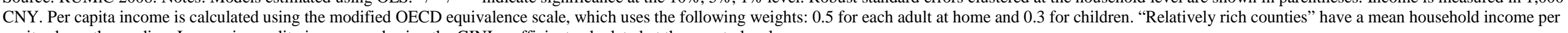
capita above the median. Income inequality is measured using the GINI coefficient calculated at the county level. 
Table 6: Robustness, Self-Selection into Migration, and Net Remittances

\begin{tabular}{|c|c|c|c|c|c|c|}
\hline & \multicolumn{3}{|c|}{ Further Sensitivity Checks } & \multicolumn{2}{|c|}{ Selection Correction } & \multirow{2}{*}{$\begin{array}{c}\text { Net Remittances } \\
\text { Instrument: } \\
\text { Distance, Birth } \\
\text { Order } \\
\end{array}$} \\
\hline & Ordered Probit & Median Income & With GHQ11 & $\begin{array}{l}\text { Instrument 1: } \\
\text { Distance }\end{array}$ & $\begin{array}{c}\text { Instrument 2: } \\
\text { Distance, Birth } \\
\text { Order }\end{array}$ & \\
\hline Log HH income pc & $\begin{array}{l}0.078^{* * *} \\
(0.021)\end{array}$ & $\begin{array}{l}0.337^{* * *} \\
(0.089)\end{array}$ & $\begin{array}{l}0.219 * * * \\
(0.068)\end{array}$ & $\begin{array}{l}0.199 * * \\
(0.084)\end{array}$ & $\begin{array}{l}0.197^{* *} \\
(0.084)\end{array}$ & $\begin{array}{l}0.015^{* * *} \\
(0.004)\end{array}$ \\
\hline County mean Log $\mathrm{HH}$ income pc & $\begin{array}{l}-0.199 * * * \\
(0.048)\end{array}$ & $\begin{array}{l}-0.784 * * * \\
(0.217)\end{array}$ & $\begin{array}{l}-0.541^{* * *} \\
(0.175)\end{array}$ & $\begin{array}{l}-0.778 * * * \\
(0.219)\end{array}$ & $\begin{array}{l}-0.741^{* * *} \\
(0.217)\end{array}$ & $\begin{array}{l}-0.037 * * \\
(0.016)\end{array}$ \\
\hline Log remittances pc & $\begin{array}{c}0.016 \\
(0.016)\end{array}$ & $\begin{array}{c}0.086 \\
(0.070)\end{array}$ & $\begin{array}{l}0.097^{*} \\
(0.056)\end{array}$ & $\begin{array}{l}-0.073 \\
(0.066)\end{array}$ & $\begin{array}{l}-0.079 \\
(0.066)\end{array}$ & $\begin{array}{c}0.012 \\
(0.008)\end{array}$ \\
\hline County mean Log remittances pc & $\begin{array}{l}0.204^{* * *} \\
(0.041)\end{array}$ & $\begin{array}{l}0.664^{* * *} \\
(0.124)\end{array}$ & $\begin{array}{l}0.619 * * * \\
(0.147)\end{array}$ & $\begin{array}{l}0.821^{* * *} \\
(0.185)\end{array}$ & $\begin{array}{l}0.822^{* * *} \\
(0.186)\end{array}$ & $\begin{array}{l}0.031^{* *} \\
(0.015)\end{array}$ \\
\hline $\begin{array}{l}\text { Rho (correlation between } \\
\text { equations) }\end{array}$ & & & & $\begin{array}{l}0.106 * \\
(0.061)\end{array}$ & $\begin{array}{l}0.108 * \\
(0.062)\end{array}$ & \\
\hline R-Squared & 0.045 & 0.239 & 0.437 & & & 0.235 \\
\hline Observations & 11624 & 11624 & 12174 & 16222 & 16156 & 11542 \\
\hline
\end{tabular}

Notes: Models are estimated using OLS. Income inequality is measured using the GINI coefficient. See Table 2 for the full specification. $* / * * * * *$ indicate significance at the $10 \%, 5 \%, 1 \%$ level. Standard errors are in parentheses. 